\title{
Comparative study on the application of green accounting based on university social responsibility at Universities in Pontianak
}

\author{
Henri Prasetyo, ${ }^{1}$ Ika Kurnia Indriani, ${ }^{2}$ Agus Widodo ${ }^{3}$ \\ 1,2,3Politeknik Negeri Pontianak, Indonesia \\ email: henriprasetyo@gmail.com
}

\begin{abstract}
Purpose - The purpose of this research is to know the difference of university social responsibility on green accounting implementation at Tanjungpura University with other universities in Pontianak City. Green accounting is a style of accounting that describes efforts to incorporate environmental benefits and costs into making economic decisions or business financial results.
\end{abstract}

Method - The objects of this research are audit committee, internal auditors, internal supervisory units and officers, lecturers, or staff at universities in Pontianak City who know about responsibility in managing the environment. This study uses accidental sampling in Tanjungpura University, Pontianak State Polytechnic, Muhammadiyah University of Pontianak, and Panca Bhakti University. The data analysis in this study was done by using Mann WhitneyU-test.

Result - The results of this study indicate that there are significant differences between the Tanjungpura University with other universities in Pontianak City on environmental involvement, environmental reporting, and environmental audit; while for environmental concern, there is no difference between the University Tanjungpura with other universities in the Pontianak City.

Implication - Universities in Pontianak City are suggested to improve their performance related to the environment, especially in environmental involvement, environmental reporting, and environmental audit.

Originality - This research is the first study that used four universities as the research objects.

Keywords: green accounting; university social responsibility; environmental concern and involvemnet; environmental reporting and audit

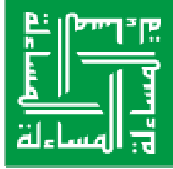

Journal of Islamic Accounting and Finance Research 
Henri Prasetyo, Ika Kurnia Indriani, Agus Widodo

\section{Introduction}

Environmental issues began to be discussed a lot in the last decade. Accounting is a form of adjusting the company's business activities from JIAFR | 186 environmental issues. Kartikasari (2012) and Rizki, Agriyanto \& Farida (2019) discloses accounting as calculate science which means that accounting applies environmental cost calculations in the implementation of its knowledge for company transparency in disclosing environmental information as a result of the company's business activities. Accounting science that studies specifically in the field of environment is called green accounting or also known as environmental accounting.

Corporate social responsibility is a mechanism for organizations to voluntarily integrate environmental and social concerns into their operations and interactions with stakeholders, which go beyond the organization's responsibility in the legal field (Kusmana \& Sumilir, 2020). Stakeholder theory explains the importance of organizational accountability over financial or economic performance, one of which is manifested through environmental performance reports. Kartikasari's (2012) research conclusions revealed that respondents who were concerned with the environment that prompted them to pay attention to environmental problems tended to be influenced by complaints about company products. Besides that, there were also demands from stakeholders, such as consumers, society, and owners of capital.

The results of Anggraini's research (2006) indicate that less than 5\% of companies listed on the IDX from 2000-2004 reported their environmental performance. Lindrianasari (2007) states in her research that only companies that have good environmental performance will also do environmental disclosure well. There is a need for a strong will to include environmental costs in the company's accounting system. This push also involves management accountants, stakeholders, implementation, and supervision more intensively to ensure all environmental costs can be included in the accounting system (Kartikasari, 2012). 
Higher education is an organization that has big social and environmental responsibilities. Social responsibility in the realm of higher education is called university social responsibility (USR) which is in line with corporate social responsibility (CSR) in companies. Astiti (2014) states that in Indonesia, the accounting standards used as a reference do not oblige tertiary institutions to disclose social information relating to the activities carried out, particularly the university's responsibility for the environmental impacts undertaken. Publication of environmental-related reports at several universities in Indonesia is still low according to research by Lubis et al. (2018) that studied USR at UIN Maulana Ibrahim Malang and also research by Astiti (2014) that studied USR at Yogyakarta State University. Even though Burhany (2014) explained in his research that if the implementation of environmental accounting is good, it will have an impact on the performance and disclosure of environmental information that is also good.

In Pontianak City, the discourse on green accounting has not received much attention in almost all tertiary institutions. Some students and employees of the University of Tanjungpura Pontianak have complained about environmental problems, which include the lack of trash bins so that the campus often looks dirty due to littering. Besides, the roads around the undergraduate campus area are found with holes and cracks that make vehicle users feel uncomfortable when passing through the area. The area of the Sylva Indonesia Arboretum, which is an urban forest, was also found scattered about and some orchids have not been cared for. Even the park that used to look beautiful around the rectorate area is no longer there due to a construction project that has leveled all the parks. The emergence of several problems at Tanjungpura University raises questions about whether universities in Pontianak City have special attention and concern in the environmental field as a form of social and environmental responsibility, and whether universities in Pontianak City have differences in the application of green accounting based on university social responsibility. 


\section{Literature Review}

\section{Stakeholder Theory}

Stakeholder theory explains that a company is not an entity that only operates for its interests, but also to provide benefits to stakeholders (Ghozali \& Chariri, 2007). Stakeholder theory is a theory that explains how organizational management fulfills or manages stakeholder desires. Stakeholder theory emphasizes the importance of accountability for organizational accountability far beyond financial or economic performance. This theory states that organizations will prefer to voluntarily disclose information about their environmental, social, and intellectual performance, more than their mandatory demand to meet actual or expected expectations of stakeholders (Deegan, 2014).

\section{Green Accounting}

According to Cohen \& Robbins (2011), green accounting is the activity of collecting, analyzing, estimating, and preparing reports on both environmental and financial data aimed at reducing environmental impact and costs. This form of accounting focuses on several aspects of government policy as well as possible. Consequently, environmental accounting has become an important aspect of a green business concept and responsible economic development.

\section{University Social Responsibility}

The form of social and environmental responsibility accounting in companies is known as Corporate Social Responsibility (CSR) or it can also be called Sustainability Reporting (SR) (Setiyawan, Prasetyoningrum \& Farida, 2020). In financial reports, social responsibility accounting can be reported separately from the annual financial reports. Lately, CSR has become increasingly popular and has become the company's attention following the theory of legitimacy in which companies try to make efforts as a form of fulfilling the expectations of the parties involved (stakeholders) to get support 
and trust from the community. CSR is an organizational mechanism that integrates social and environmental concerns in their business operations and their interactions with stakeholders voluntarily (Anggraini, 2006).

In higher education, CSR is known in the form of University Social Responsibility (CSR). USR is a responsibility shared by universities in contributing to social improvement through the integration of social responsibility policies into institutional management, teaching, research, services, and public activities. Some examples of USR's mission include building communities inside and outside the university that promote social responsibility across multiple stakeholders; promotion of activities that are ethical, inclusive, and beneficial to the public; emphasis on environmental conservation, sustainability, and balanced social development; increasing the welfare and quality of life of the people, especially the needy and vulnerable people; and a commitment to building a better world (Shek \& Hollister, 2017). Several universities have adopted CSR as an aspect of their competitive advantage. In Indonesia, the accounting standards used as a reference do not oblige universities to disclose social information related to the activities they carry out. Especially in the responsibility of higher education towards environmental impacts resulting from the activities carried out. This obligation makes universities have to assess the benefits and disadvantages before deciding whether to implement USR or not.

\section{Application of Green Accounting based on University Social Responsibility}

Susilo (2008) revealed that the application of green accounting based on university social responsibility in higher education consists of:

\section{Environmental concern}

The theory of environmental concern states that efforts to involve every citizen in growing and fostering awareness to preserve the environment is based on values, that is the value system of the environment itself with a philosophy of living peacefully with its natural environment (Jahamani, 2003). 


\section{Environmental Involvement}

Environmental involvement is the company's commitment to participate in sustainable economic development to improve the quality of life and the environment that is beneficial for the company itself and the local community and the general public. (Musyarofah, 2013). This environmental involvement provides social responsibility for the organization to respond or take proactive action against the expectations of the community for the implementation of its activities (Teoh \& Thong, 1984).

\section{Environmental Reporting}

The organizational environmental accounting reporting theory states that accountability can be met and information asymmetry can be reduced if the organization reports and discloses its CSR activities to stakeholders. By reporting and disclosing CSR, stakeholders will be able to evaluate how CSR is implemented and provide rewards or sanctions to organizations according to the results of their evaluation. CSR reporting is not only beneficial for external parties, but also the organization. By making a CSR report, the organization will carry out a self-assessment so that it can identify the strengths and weaknesses of the company related to CSR activities in the organization (Dunk, 2002).

\section{Environmental Audit}

An environmental audit is a comprehensive inspection tool in an environmental management system to objectively verify environmental management efforts and can help look for remedial measures to improve environmental performance (Sari, Prasetyoningrum \& Hartono, 2020). To ascertain whether the performance of an organization's environmental conservation program is running effectively and efficiently, it is necessary to have an environmental performance audit. With the environmental performance audit, the performance of the environmental conservation program carried out by the organization can be seen (Dunk, 2002). 


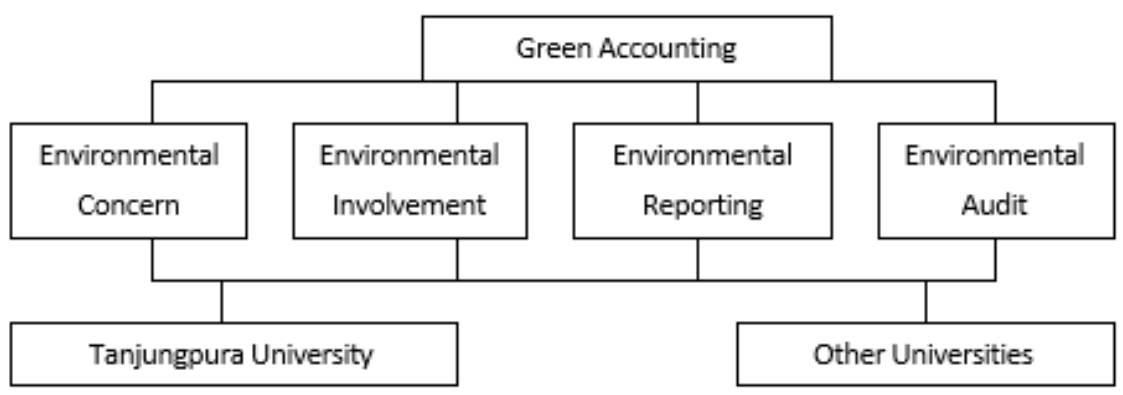

JIAFR | 191

Figure 1. Conceptual Framework

This research framework describes the implementation of green accounting based on university social responsibility at Tanjungpura University (Untan) with other universities (non Untan) in Pontianak. Based on the analysis on the theoretical basis and previous research on the analysis of the implementation of green accounting, four variables explain the application of green accounting in universities, namely: environmental concern, environmental involvement, environmental reporting, and environmental audit. These variables are used to show the differences between Tanjungpura University and other universities in Pontianak in implementing green accounting based on university social responsibility.

\section{Hypothesis Development}

\section{Differences in Environmental Concern between Tanjungpura University and Other Universities in Pontianak}

Environmental concern is an early stage for universities to implement green accounting to build awareness and commitment to the importance of USR (Sari \& Hadiprajitno, 2013). In the environmental concern variable, the research focuses on the conditions that cause the respondents to pay attention to environmental problems. This concept of environmental concern states that efforts to involve every citizen in growing and fostering awareness to preserve the environment are based on values, which are the values of the 
environment itself with a philosophy of living peacefully with its natural environment (Jahamani, 2003). Dealing with the environmental concern, a hypothesis can be formulated as follows:

JIAFR | 192

$H_{1}$ : There are differences in environmental concerns between Tanjungpura University and other universities in Pontianak

\section{Differences in Environmental Involvement between Tanjungpura University and Other Universities in Pontianak}

Environmental involvement is a further stage after universities have a concern for the environment into real action in the application of USR-based green accounting (Sari \& Hadiprajitno, 2013). Environmental involvement is the company's commitment to participate in sustainable economic development to improve the quality of life and the environment that is beneficial for the company itself and the local community as well as the public in general (Musyarofah, 2013). Organizational social involvement arises as a response or proactive action taken by the organization against community expectations for the implementation of its activities. Based on the elaboration, a hypothesis can be formulated as follows:

$\mathrm{H}_{2}$ : There are differences in environmental involvement between

Tanjungpura University and other universities in Pontianak

\section{Differences in Environmental Reporting between Tanjungpura University and Other Universities in Pontianak}

Environmental reporting is a necessary stage after universities realize the implementation of green accounting for the decision-making process as well as to disclose material and relevant information about tertiary institutions (Sari \& Hadiprajitno, 2013). Environmental reporting is measured based on the response to the availability of an entity's environmental performance report (Dunk, 2002). Based on these concepts, a hypothesis can be formulated as follows:

$H_{3}:$ There are differences in environmental reporting between

Tanjungpura University and other universities in Pontianak 
Comparative study on the application of green accounting based on ...

\section{Differences in Environmental Audit between Tanjungpura University and Other Universities in Pontianak}

Environmental audit is the last stage in the application of green JIAFR | 193 accounting in universities to ensure the performance of the environmental conservation program that has been carried out is running effectively and efficiently by conducting an environmental performance audit (Sari \& Hadiprajitno, 2013). Environmental auditing is a systematic process that needs to be carefully planned, structured, and organized. Since environmental auditing is part of a long-term evaluation and screening process, it should be an iterative process so that, if necessary, different groups can repeat it and compare results to reflect quantitative and qualitative changes (Hemmatfar et al., 2010). By referring to the theories, the fourth hypothesis can be formulated as follows:

$H_{4}: \quad$ There are differences in environmental audits between Tanjungpura University and other universities in Pontianak

\section{Research Methods}

The data collection method in this study is a survey method that is by distributing questionnaires to respondents directly. The questionnaire used is in the form of written questions which contain stakeholder perceptions regarding the application of green accounting based on university social responsibility in universities in Pontianak City. The object of this research is the audit committee, internal auditors, internal control units and officials, lecturers, or staff at universities in Pontianak City who know about their responsibility in managing the environment. The universities chosen were Tanjungpura University, Pontianak State Polytechnic, Pontianak Muhammadiyah University, and Panca Bhakti University.

The sampling pattern was carried out by accidental sampling. Accidental sampling is a sampling technique that makes anyone who happens to meet 
the researcher can be used as a sample if the person met is considered suitable as a data source.

In this variable, the study concerns the conditions that cause respondents JIAFR | 194 to pay attention to environmental problems. Environmental concern variables are measured by: a) The existence of regulations regarding the environment. b) There is a philosophy from higher education leaders that supports environmental concerns. c) There is support from various stakeholders to increase environmental concerns. d) The support of human resources (HR) and economic resources (SDE) related to environmental concerns. e) There is support for a master plan for research and community service related to the environment. f) There is a realization of research and community service related to the environment. Measurement of environmental concern variables using a likert scale of 1 to 5 with criteria 1 indicating strongly disagree to 5 indicating strongly agree.

The criteria to measure environmental involvement in higher education, according to Teoh \& Thong (1984) are: a) The existence of environmental units in universities. b) Availability of funds for environmental protection. c) Availability of programs or procedures that reduce the consumption of natural resources. d) Availability of environmental safety studies if the entity uses machines in its operational activities. Measurement of environmental involvement variables using a likert scale of 1 to 5 with criteria 1 indicating strongly disagree to 5 which indicates strongly agree.

This variable is measured based on the answer to the availability of the entity's environmental performance report which includes (Dunk, 2002): a) Environmental performance report. b) Performance reports are reported on an ongoing basis. c) Performance report published. d) Environmental performance reports attach publications. Measurement of environmental reporting variables using a likert scale of 1 to 5 with criteria 1 indicates strongly disagree to 5 which indicates strongly agree.

This last variable is measured based on the answer to the availability of a higher education environmental performance audit report which includes: a) 
There is an audit report on green accounting in college. b) There is an internal supervisory unit (SPI) regarding green accounting in universities Measurement of environmental audit variables using a likert scale of 1 to 5 with criteria 1 indicates strongly disagree to 5 which indicates strongly agree.

The purpose of data analysis is to obtain relevant information contained JIAFR | 195 in the data and use the results to solve a problem (Ghozali, 2011). Descriptive statistics are statistics that are used to analyze data by describing the collected data as it is without making generalized conclusions or generalizations. Descriptive statistics provide an overview or description of data that is seen as the average, standard deviation, variant, maximum, and minimum (Ghozali, 2011).

A reliability test is a test used to measure a questionnaire that uses indicators of variables or constructs. A questionnaire is considered reliable if someone's answer to a question is consistent or stable over time (Ghozali, 2011). A construct or variable is considered reliable if it gives a Cronbach's alpha value $>0.70$.

The validity test is used to measure whether a questionnaire is valid or not. A questionnaire is considered valid if the questions on the questionnaire can reveal something that will be measured by the questionnaire (Ghozali, 2011). This validity test uses the Pearson correlation, which is by comparing the correlation between each question score and the total question score. If the significance value of the Pearson correlation obtained has a significance value $<0.05$, it means that the data obtained is valid.

The normality test was performed using the Kolmogorov-Smirnov test. The assumption of normality is a requirement of most inferential statistical procedures. The purpose of the normality test is to test whether in a regression model, the independent variable, the dependent variable, or all three have a normal distribution or not. The data is normally distributed if the significance value of the Kolmogorov-Smirnov test $>0.05$.

Different test using independent sample T-test was conducted to determine whether there were differences in perceptions of universities in 
Pontianak in the application of green accounting based on university social responsibility (USR) which was measured by four variable indicators; environmental concern, environmental involvement, environmental reporting, and environmental audit. Independent sample T-test is used if the normality test results show that the data is normally distributed. To find out that there are differences in perceptions, it can be done by looking at the value of Levene's test for equality of variances. If the significance value is $<0.05$, there is a difference in perception between Tanjungpura University and other universities in Pontianak City.

The Mann Whitney U-test was calculated to determine the difference in the variables. This consideration is made because the data is ordinal, the sample data is large, and the number of samples is not the same. Testing with the Mann Whitney U-test was carried out using grouping variables based on each hypothesis from the perceptions of respondents in universities in Pontianak City. In each variable, the total question score for each sample of environmental problems is entered into the variable list box. If the significance value of the Mann Whitney U-test $<0.05$, there is a difference in perception between Tanjungpura University and other universities in Pontianak City.

\section{Results and Discussion}

Based on the results of the questionnaire distribution, the total number of respondents was 93 people; 43 respondents coming from Tanjungpura University, 20 respondents from Pontianak State Polytechnic, 18 respondents from Pontianak Muhammadiyah University, and 12 respondents from Panca Bhakti University.

\section{Descriptive statistics}

According to Santoso (2001), the descriptive statistical analysis aims to determine the characteristics of the data, such as the minimum, maximum, average value, and how far the data varies. The following describes descriptive statistics of research data in table 2 . 
Comparative study on the application of green accounting based on ...

Table 1. Number of Research Respondents

\begin{tabular}{|c|c|c|c|c|c|}
\hline No & College & $\begin{array}{c}\text { Distributed } \\
\text { questionnaires }\end{array}$ & $\begin{array}{l}\text { Non-returned } \\
\text { questionnaire }\end{array}$ & $\begin{array}{l}\text { Incomplete } \\
\text { questionnaire }\end{array}$ & $\begin{array}{l}\text { The } \\
\text { questionnaire is } \\
\text { ready to be } \\
\text { processed }\end{array}$ \\
\hline 1 & $\begin{array}{l}\text { Tanjungpura } \\
\text { University }\end{array}$ & 60 & 10 & 7 & 43 \\
\hline 2 & $\begin{array}{l}\text { Pontianak State } \\
\text { Polytechnic } \\
\text { Muhammadiyah }\end{array}$ & 20 & 0 & 0 & 20 \\
\hline 3 & $\begin{array}{l}\text { University } \\
\text { Pontianak }\end{array}$ & 20 & 0 & 2 & 18 \\
\hline 4 & $\begin{array}{l}\text { Panca Bhakti } \\
\text { University }\end{array}$ & 20 & 3 & 5 & 12 \\
\hline & Total & 120 & 13 & 14 & 93 \\
\hline
\end{tabular}

Source: Primary data processed, 2018

Table 2. Number of Respondents in Higher Education

Frequency Percent Valid Percent Cumulative Percent

\begin{tabular}{lllccc}
\hline Valid & 1 & 43 & 46.2 & 46.2 & 46.2 \\
& 2 & 50 & 53.8 & 53.8 & 100.0 \\
& Total & 93 & 100.0 & 100.0 & \\
\hline
\end{tabular}

Source: Primary data processed, 2018

Table 3. Variable Descriptive Statistics

\begin{tabular}{|c|c|c|c|c|}
\hline \multirow{3}{*}{ Variable } & \multicolumn{4}{|c|}{ Type of College } \\
\hline & \multicolumn{2}{|c|}{ Camel } & \multicolumn{2}{|c|}{ Non Untan } \\
\hline & Mean & Std. Deviation & Mean & Std. Deviation \\
\hline Environmental concern & 4.19477 & 0.42982 & 4.06000 & 0.64099 \\
\hline Environmental & 3.98837 & 0.57594 & 3,70750 & 0.59097 \\
\hline Environmental reporting & 4.05349 & 0.65514 & 3,75600 & 0.62275 \\
\hline Environmental audit & 4.15698 & 0.59767 & 3.67000 & 0.84280 \\
\hline
\end{tabular}

Source: Primary data processed, 2018

Journal of Islamic Accounting and Finance Research - Vol. 2 No. 2 (2020) 
Based on table 2, the number of respondents shows that 43 out of 93 respondents or $46.2 \%$ are respondents from Tanjungpura University, while 50 out of 93 or $53.8 \%$ are respondents outside Tanjungpura University. The following is a descriptive statistical table that explains the average value and standard deviation of this research variable in table 3.

\section{Reliability Test}

The reliability test resulted in the Cronbach's alpha value for each variable that was greater than 0.70 . Thus, the questionnaires/indicators of the variables of environmental concern, environmental involvement, environmental reporting, and environmental audit are reliable as variable measuring tools.

\section{Validity test}

The result of the correlation shows that the significance value between the respondents' answers in each question and the total value of the respondents' answers is 0.000 , which means that it is significantly correlated at the significance level $\alpha=0.05$. It shows that the questionnaires/indicators used by the variables of environmental concern, environmental involvement, environmental reporting, and environmental auditing are considered valid to be used as variable measuring tools.

\section{Normality test}

The normality test using the Kolmogorov-Smirnov test shows that all variables do not have a normal distribution. It is indicated by a significance value of less than 0.05 for the variables of environmental concern, environmental involvement, environmental reporting, and environmental audit. Because the data are not normally distributed for all variables, hypothesis testing uses the Mann Whitney U-test. 
Comparative study on the application of green accounting based on ...

Table 4. Reliability Test Results

\begin{tabular}{lcl}
\hline \multicolumn{1}{c}{ Variable } & Cronbach's Alpha Results & Remark \\
\hline Environmental concern & $0.872>0.70$ & Reliable \\
Environmental involvement & $0.832>0.70$ & Reliable \\
Environmental reporting & $0.910>0.70$ & Reliable \\
Environmental audit & $0.948>0.70$ & Reliable \\
\hline
\end{tabular}

JIAFR | 199

Source: Primary data processed, 2018

Table 5. Validity Test Results

\begin{tabular}{|c|c|c|c|}
\hline Variable & Indicator & Significance & Remark \\
\hline \multirow{8}{*}{ Environmental concern } & KEPEL L1 & $0.000<0.05$ & Valid \\
\hline & KEPEL_L2 & $0.000<0.05$ & Valid \\
\hline & KEPEL_L3 & $0.000<0.05$ & Valid \\
\hline & KEPEL_L4 & $0.000<0.05$ & Valid \\
\hline & KEPEL L5 & $0.000<0.05$ & Valid \\
\hline & KEPEL_L6 & $0.000<0.05$ & Valid \\
\hline & KEPEL_L7 & $0.000<0.05$ & Valid \\
\hline & KEPEL L8 & $0.000<0.05$ & Valid \\
\hline \multirow{8}{*}{ Environmental Involvement } & KETER L1 & $0.000<0.05$ & Valid \\
\hline & KETER L2 & $0.000<0.05$ & Valid \\
\hline & KETER L3 & $0.000<0.05$ & Valid \\
\hline & KETER L4 & $0.000<0.05$ & Valid \\
\hline & KETER_L5 & $0.000<0.05$ & Valid \\
\hline & KETER_L6 & $0.000<0.05$ & Valid \\
\hline & KETER_L7 & $0.000<0.05$ & Valid \\
\hline & KETER L8 & $0.000<0.05$ & Valid \\
\hline \multirow{10}{*}{ Environmental Reporting } & PEL_L1 & $0.000<0.05$ & Valid \\
\hline & PEL L2 & $0.000<0.05$ & Valid \\
\hline & PEL L3 & $0.000<0.05$ & Valid \\
\hline & PEL L4 & $0.000<0.05$ & Valid \\
\hline & PEL_L5 & $0.000<0.05$ & Valid \\
\hline & PEL_L6 & $0.000<0.05$ & Valid \\
\hline & PEL L7 & $0.000<0.05$ & Valid \\
\hline & PEL L8 & $0.000<0.05$ & Valid \\
\hline & PEL L9 & $0.000<0.05$ & Valid \\
\hline & PEL L10 & $0.000<0.05$ & Valid \\
\hline
\end{tabular}

Journal of Islamic Accounting and Finance Research - Vol. 2 No. 2 (2020) 
Henri Prasetyo, Ika Kurnia Indriani, Agus Widodo

\begin{tabular}{llll}
\hline & AUDIT_L1 & $0.000<0.05$ & Valid \\
Environmental Audit & AUDIT_L2 & $0.000<0.05$ & Valid \\
& AUDIT_L3 & $0.000<0.05$ & Valid \\
& AUDIT L4 & $0.000<0.05$ & Valid \\
\hline
\end{tabular}

JIAFR | 200 Source: Primary data processed, 2018

Table 6. Normality Test

\begin{tabular}{lcc}
\hline \multicolumn{1}{c}{ Variable } & Significance & \multicolumn{1}{c}{ Remark } \\
\hline Environmental concern & 0,023 & Distribution is not normal \\
Environmental Involvement & 0,037 & Distribution is not normal \\
Environmental Reporting & 0,047 & Distribution is not normal \\
Environmental Audit & 0,001 & Distribution is not normal \\
\hline
\end{tabular}

Source: Primary data processed, 2018

\section{Hypothesis Test}

Table 7 shows that environmental concern has a significance value of $0.269>0.05$. It can be concluded that the first hypothesis which indicates a significant difference in environmental concern between Tanjungpura University and other universities in Pontianak is rejected.

Environmental involvement has a significance value of $0.048<0.05$. It can be concluded that the second hypothesis which indicates a significant difference in environmental involvement between Tanjungpura University and other universities in Pontianak is accepted.

Environmental reporting has a significance value of $0.013<0.05$. It can be concluded that the third hypothesis which indicates a significant difference in environmental reporting between Tanjungpura University and other universities in Pontianak is accepted.

The environmental audit has a significance value of $0.011<0.05$. It can be concluded that the fourth hypothesis which indicates a significant difference in environmental audit between Tanjungpura University and other universities in Pontianak is accepted. 
Comparative study on the application of green accounting based on ...

Table 7. Results of Hypothesis Test

\begin{tabular}{lccc}
\hline \multicolumn{1}{c}{ Variable } & Sig. & Remark & Ha \\
\hline Environmental concern & 0,269 & Sig. $>0,05$ & rejected \\
Environmental involvement & 0,048 & Sig. $<0,05$ & accepted \\
Environmental reporting & 0,013 & Sig. $<0,05$ & accepted \\
Environmental audit & 0,011 & Sig. $<0,05$ & accepted \\
\hline
\end{tabular}

JIAFR | 201

Source: Primary data processed, 2018

\section{Differences in Environmental Concern between Tanjungpura University and Other Universities in Pontianak}

The results of the hypothesis testing in table 7 show that there is no significant difference in environmental concern between Tanjungpura University and other universities in Pontianak. Environmental concern is one of the factors that can explain a university to implement green accounting. The policies in each tertiary institution which are based on the Tri Dharma of Higher Education have resulted in the same way of thinking in universities in Pontianak City regarding environmental management. It shows that universities in Pontianak City have a concern for the campus environment. This statement is supported by data processing in table 8 which shows that Tanjungpura University and other universities in Pontianak City have an average answer in category 4 (agree).

Table 8 shows that there is no significant difference between the respondents' perceptions at Tanjungpura University and other universities in Pontianak City regarding the environmental concern. The average respondents at Tanjungpura University answered the questionnaire for environmental concern variables of 4.19477. It is not much different from the average respondents outside the University of Tanjungpura who answered the questionnaire for environmental concern variables of 4.06000. So, it can be concluded through the data that universities in Pontianak City have a sense of concern for the environment at the same level. The results of this study are consistent with the results of the studies by Susilo (2008), Sari \& 
Henri Prasetyo, Ika Kurnia Indriani, Agus Widodo

Hadiprajitno (2013), and Susilo \& Astuti (2014) that there is no significant difference in respondents' perceptions of environmental concern.

\section{Differences in Environmental Involvement between Tanjungpura University}

JIAFR | 202

\section{and Other Universities in Pontianak}

The results of the hypothesis testing in table 7 show that there are significant differences in terms of environmental involvement between Tanjungpura University and other universities in Pontianak. Environmental involvement is a further factor in the realization of environmental concern in universities that apply green accounting. The realization of the form of environmental concern from the University of Tanjungpura is higher than that of other universities in Pontianak City. This statement is supported by data processing in table 9 which shows that Tanjungpura University has an average of 3,98837 which is higher than other tertiary institutions in Pontianak City which is 3.7075 . It reveals the respondents' perceptions about environmental involvement from Tanjungpura University are better than other universities in Pontianak City.

Table 8. The difference in Environmental Concern

\begin{tabular}{cc}
\hline \multicolumn{2}{c}{ Average Environmental Concern } \\
\hline Untan & Non Untan \\
4.19477 & 4.06000
\end{tabular}

Source: Primary data processed, 2018

Table 9. Disagreement on Environmental Involvement

\begin{tabular}{ccc}
\hline \multicolumn{3}{c}{ Percentage of Respondents Who Answered } \\
Score $\mathbf{1}$ (Strongly Disagree) and Score $\mathbf{2}$ (Disagree) \\
\hline Untan & Non Untan & Total \\
28 & 51 & 79 \\
$35,44 \%$ & $64,56 \%$ & $100 \%$ \\
\hline
\end{tabular}

Source: Primary data processed, 2018

Journal of Islamic Accounting and Finance Research - Vol. 2 No. 2 (2020) 
Table 9 shows disagreements regarding environmental involvement at the University of Tanjungpura with other tertiary institutions. The results of data processing show that Tanjungpura University has a percentage of $35.44 \%$ of respondents who chose scores 1 and 2, while other universities have a percentage of $64.56 \%$. It shows that scores 1 and 2 are not much chosen at Tanjungpura University than other universities in Pontianak City. So, it can be concluded through the data that Tanjungpura University and universities in Pontianak City in realizing environmental concerns are at different levels. The results of this study are consistent with the results of the studies by Susilo (2008), Susilo \& Astuti (2014), and Musyarofah (2013) who get the result that there are significant differences in respondents' perceptions of environmental involvement. However, the results of this study are different from the research by Sari \& Hadiprajitno (2013) which gets the opposite result.

\section{Differences in Environmental Reporting between Tanjungpura University and Other Universities in Pontianak}

The results of the hypothesis testing in table 7 show that there is a significant difference in environmental reporting between Tanjungpura University and other universities in Pontianak. Environmental reporting can be used as material for evaluation in the implementation of environmental activities and can also provide rewards or sanctions to institutions according to the evaluation results of these activities. Environmental reporting can even be used to identify the strengths and weaknesses of institutions related to environmental activities that are realized. Transparent reporting should be an obligation that generates added value for higher education. The results of the data processing in table 10 show that Tanjungpura University has better environmental reporting because it has an average of 4.05349 which is greater than other universities of 3.756. It shows that respondents at the University of Tanjungpura agree that the environmental reporting in which they work is categorized as good, while respondents in other universities still 
have doubts about the environmental reporting in which they work is categorized as good.

Table 10 shows that there is a large difference between the perceptions of respondents at Tanjungpura University and other universities in Pontianak City regarding environmental reporting. The average respondents at Tanjungpura University answered the questionnaire for environmental reporting variables of 4.05349. It is different from the average respondents outside Tanjungpura University who answered the questionnaire for environmental reporting variables of 3.75600 . So, it can be concluded from the data that Tanjungpura University and other universities in Pontianak City reported environmental activities that had been realized at different levels. The results of this study are following the results of studies by Susilo (2008), Susilo \& Astuti (2014), and Musyarofah (2013) that there are significant differences in respondents' perceptions of environmental reporting. However, the results of this study are different from the research results by Sari \& Hadiprajitno (2013) which get the opposite result.

Table 10. The difference in Environmental Reporting

\begin{tabular}{cc}
\hline \multicolumn{2}{c}{ Environmental Reporting Average } \\
\hline Untan & Non Untan \\
4.05349 & 3.75600 \\
\hline Source: Primary data processed, 2018 & \\
Table 11. The difference in the Environmental Audit & \\
\hline \multicolumn{2}{c}{ Average Audit Discussion } \\
\hline Untan & Non Untan \\
4.15698 & 3.67000 \\
\hline
\end{tabular}

Source: Primary data processed, 2018 


\section{Differences in Environmental Audit between Tanjungpura University and Other Universities in Pontianak}

The results of the hypothesis testing in table 7 show that there is a significant difference in environmental audit between Tanjungpura University and other universities in Pontianak. An environmental audit is a comprehensive inspection tool in an environmental management system to objectively verify environmental management efforts and can help look for remedial measures to improve environmental performance. The existing environmental audit at Tanjungpura University brought better results than the Pontianak City universities in their environmental activities. It refers to the data in table 11 which shows that Tanjungpura University has an average answer in category 4 (agree), in contrast to other universities in Pontianak City which have an average answer in category 3 (doubtful). It explains the perception of respondents from Tanjungpura University that they believe that the college where they work has a good environmental audit. Meanwhile, the perception of respondents outside Tanjungpura University is not sure that the college where they work has a good environmental audit.

Table 11 shows that there is a large difference between the perceptions of respondents at Tanjungpura University and other universities in Pontianak City regarding the environmental audit. The average respondents at Tanjungpura University answered the questionnaire for the environmental audit variable of 4.15698. It is different from the average respondents outside the University of Tanjungpura who answered the questionnaire for environmental audit variables of 3.67000 . So, it can be concluded through the data that the audit treatment environment at Tanjungpura University with other universities is at a different level. The results of this study are following the results of studies by Susilo (2008), Susilo \& Astuti (2014), and Musyarofah (2013) that there are significant differences in the perceptions of respondents in environmental audits. However, the results of this study are different from the results of the study by Sari \& Hadiprajitno (2013) which gets the opposite result. 


\section{Conclusion}

Based on the results of the data analysis previously discussed, it can be concluded that there are significant differences between Tanjungpura University and other universities in Pontianak City on the variables of environmental involvement, environmental reporting, and environmental audit. Meanwhile, for the environmental concern variable, there is no significant difference between Tanjungpura University and other universities in Pontianak City.

Universities in Pontianak City have to improve their performance related to the environment, especially in terms of environmental involvement, environmental reporting, and environmental audit. This research was only conducted at universities in Pontianak City. For further research, it is suggested that the number of respondents is increased by involving universities from other cities to compare the quality of research results. For research substance, the material used in this research is still general. For this reason, in future research, the substance of the material can be focused on problems of water pollution, air, land waste, and the like.

\section{References}

Anggraini, F. R. R. (2006). Pengungkapan Informasi Sosial dan Faktor-Faktor yang Mempengaruhi Pengungkapan Informasi Sosial dalam Laporan Keuangan Tahunan. Pengungkapan Informasi Sosial Dan FaktorFaktor Yang Mempengaruhi Pengungkapan Informasi Sosial Dalam Laporan Keuangan Tahunan (Studi Empiris Pada PerusahaanPerusahaan Yang Terdaftar Bursa Efek Jakarta), 21, 23-26. http://digilib.mercubuana.ac.id/manager/file_artikel_abstrak/Isi_Arti kel_699411403487.pdf.

Astiti, W. (2014). Implementasi Green Accounting Berbasis University Social Responsibility (USR) Di Universitas Negeri Yogyakarta. Nominal, Barometer Riset Akuntansi Dan Manajemen, 3(2). https://doi.org/10.21831/nominal.v3i2.2699.

Burhany, D. I. (2014). Pengaruh Implementasi Akuntansi Lingkungan terhadap Kinerja Lingkungan dan Pengungkapan Informasi 
Lingkungan (Studi pada Perusahaan Pertambangan Umum yang Mengikuti PROPER Periode 2008-2009). Proceedings SNEB 2014, 1-8.

Cohen, N., \& Robbins, P. (2011). Green Business: An A-to-Z Guide. SAGE Publications, Inc.

Deegan, C. (2014). Financial Accounting Theory (4th ed.). McGraw-Hill Education.

Dunk, A. S. (2002). Product Quality, Environmental Accounting and Quality Performance. Accounting, Auditing \& Accountability Journal, 15(5), 719-732. https://doi.org/10.1108/09513570210448975.

Ghozali, I. (2011). Aplikasi Analisi Multivariate Dengan Program SPSS 19 (5th ed.). Badan Penerbit Universitas diponegoro.

Ghozali, I., \& Chariri, A. (2007). Teori Akuntansi (4th ed.). Badan Penerbit Universitas diponegoro.

Hemmatfar, M., Salehi, M., \& Bayat, M. (2010). Competitive Advantages and Strategic Information Systems. International Journal of Business and Management, 5(7), 158-169. https://doi.org/10.5539/ijbm.v5n7p158.

Jahamani, Y. F. (2003). Green accounting in developing countries: The case of U.A.E. and Jordan. Managerial Finance, 29(8), 37-45. https://doi.org/10.1108/03074350310768418.

Kartikasari, L. (2012). Niat Akuntan dan Akuntansi Lingkungan. EcoEntrepreneurship Seminar \& Call for Paper "Improving Performance by Improving Environment" 2012, 42.

Kusmana, A., \& Sumilir, S. (2020). The Role of People's Banking Private Vocational (BPR) Toward Development of MSME in Lebak Banten. Journal of Islamic Economics and Social Science (JIESS), 1(1), 34-42. doi:http://dx.doi.org/10.22441/jiess.2020.v1i1.004.

Lindrianasari. (2007). Hubungan antara Kinerja Lingkungan dan Kualitas Pengungkapan Lingkungan dengan Kinerja Ekonomi Perusahaan di Indonesia. Jurnal Akuntansi Dan Auditing Indonesia, 11(2), 159-172.

Lubis, N. G., Wahyuni, E. D., \& Zubaidah, S. (2018). Analisis Pengungkapan University Social Responsibility di UIN Maulana Malik Ibrahim Malang. Jurnal Akademi Akuntansi, 1(1), 54-63. https://doi.org/10.1017/CB09781107415324.004. 
Henri Prasetyo, Ika Kurnia Indriani, Agus Widodo

Musyarofah, S. (2013). Analisis Penerapan Green Accounting Di Kota Semarang. Accounting Analysis Journal, 2(3), 352-359. https://doi.org/10.15294/aaj.v2i3.2855.

JIAFR | 208

Rizki, M. K., Agriyanto, R., \& Farida, D. N. (2019). The Effect of Sustainability Report and Profitability on Company Value: Evidence from Indonesian Sharia Shares. Economica: Jurnal Ekonomi Islam, 10(1), 117-140.

Santoso, S. (2001). Buku Latihan SPSS Statistik Non Parametrik. PT Elex Media Komputindo.

Sari, M. P., \& Hadiprajitno, P. B. (2013). Pengawasan impelementasi. Jurnal Akuntansi \& Auditing, 9(2), 169-198.

Shek, D. T. L., \& Hollister, R. M. (2017). University Social Responsibility and Quality of Life. Springer Nature Singapore Pte Ltd. https://doi.org/10.1007/978-981-10-3877-8_2.

Susilo, J. (2008). Green Accounting di Daerah Istimewa Yogyakarta: Studi Kasus antara Kabupaten Sleman dan Kabupaten Bantul. Jurnal Akuntansi \& Auditing Indonesia, 12(2), 149-165.

Susilo, J., \& Astuti, N. (2014). Penyusunan Model Green Accounting Untuk Perusahaan Melalui Perhatian, Keterlibatan, Pelaporan Akuntansi Lingkungan Dan Auditnya. Permana, 5(2), 17-32.

Setiyawan, E., Prasetyoningrum, A. K., \& Farida, D. N. (2020). Analisis Perbedaan Abnormal Return Sebelum dan Sesudah Pengumuman Jakarta Islamic Index. Kompartemen: Jurnal Ilmiah Akuntansi, 17(1).

Sari, A. R., Prasetyoningrum, A. K., \& Hartono, S. B. (2020). The effect of intellectual capital and networking on the organizational values of Islamic Boarding Schools (A case study on Khalaf Islamic Boarding Schools in Demak). Journal of Islamic Accounting and Finance Research, 2(1), 69-90. https://doi.org/10.21580/jiafr.2020.2.1.5044.

Teoh, H. Y., \& Thong, G. (1984). Another look at corporate social responsibility and reporting: An empirical study in a developing country. Accounting, Organizations and Society, 9(2), 189-206. https://doi.org/10.1016/0361-3682(84)90007-2. 